\title{
Aripiprazole in the acute and maintenance phase of bipolar I disorder
}

This article was published in the following Dove Press journal:

Therapeutics and Clinical Risk Management

II January 2012

Number of times this article has been viewed

\author{
Melanie Zupancic' \\ Misty L Gonzalez ${ }^{2,3}$ \\ 'Southern Illinois University School \\ of Medicine, ${ }^{2}$ Division of Medicine \\ Psychiatry, Southern Illinois University \\ School of Medicine, ${ }^{3}$ Southern Illinois \\ University Edwardsville School of \\ Pharmacy, Southern Illinois University \\ Edwardsville, Springfield, IL, USA
}

\begin{abstract}
Bipolar affective disorder is a disabling illness with substantial morbidity and many management challenges. Traditional mood stabilizers such as lithium, valproate, and carbamazepine are often inadequate in controlling symptoms both during the acute and maintenance phase of treatment. Aripiprazole is a second-generation antipsychotic with a unique mechanism of action. Evidence suggests that it is effective in acute manic and mixed states. There are limited data to suggest its efficacy as a maintenance agent. Future studies will be needed to better define the role of aripiprazole relative to other traditional pharmacologic agents.
\end{abstract}

Keywords: aripiprazole, bipolar disorder, acute treatment, maintenance treatment

\section{Introduction}

Amongst people aged 15-44 years, bipolar affective disorder (BPAD) is the sixth leading cause of medical disability worldwide and associated with a greater degree of impairment than chronic medical conditions such as osteoarthritis, asthma, and diabetes. ${ }^{1}$ Patients report significant levels of impairment in family relationships, social relationships, and employment. ${ }^{2}$ BPAD patients have higher levels of impairment and rates of rehospitalization relative to unipolar depression patients. ${ }^{3}$ Cost of care has been estimated at USD $\$ 45$ billion. ${ }^{4}$ The monthly cost per patient of treating this illness have been estimated at USD $\$ 1600$, and exceeds that of coronary artery disease, unipolar depression, and diabetes. ${ }^{5}$

\section{Epidemiology}

BPAD is a rare yet severe psychiatric illness with an estimated lifetime prevalence of $1.6 \%{ }^{6}$ However, estimates from community samples frequently miss milder forms of BPAD resulting in the underestimation of prevalence rates. ${ }^{1}$ Expanding the diagnostic criteria to include subthreshold symptoms of mania and hypomania has resulted in prevalence estimates as high as $11.5 \% .^{7}$ An estimated $40 \%$ of patients diagnosed with major depressive disorder are reported to have subthreshold hypomanic symptoms. ${ }^{89}$ Baseline hypomanic symptoms are associated with younger age at onset, a family history of BPAD, greater levels of impairment, and increased psychiatric comorbidity. ${ }^{9}$ An estimated $20 \%$ of patients initially diagnosed with major depressive disorder will eventually go on to have a manic or hypomanic episode and the baseline presence of subtheshold hypomanic symptoms is a significant predictor of subsequent mania or hypomania. ${ }^{10}$

There is no gender partiality, although women have been reported to experience more depressive episodes over the course of illness as opposed to manic episodes. ${ }^{11-13}$
Correspondence: Melanie Zupancic PO Box 19636 Springfield,

IL 62796, USA

$\mathrm{Tel}+\mathrm{I} 2175450182$

Email mzupancic@siumed.edu
Therapeutics and Clinical Risk Management 20I2:8 I-6

(C) 2012 Zupancic and Gonzalez, publisher and licensee Dove Medical Press Ltd. This is an Open Access article

Dovepress

http://dx.doi.org/10.21 147/TCRM.S22579

which permits unrestricted noncommercial use, provided the original work is properly cited. 
Typical age of onset is between the ages of 15 and 19 years, and more than $50 \%$ of patients experience their first affective symptoms during childhood or adolescence. ${ }^{12,14}$

The elevated cost of care of this disorder is in part due to the extensive comorbidity of this population. The Epidemiologic Catchment Area Survey found an estimated $46 \%$ of patients used alcohol or were alcohol dependent, $41 \%$ used drugs or were drug dependent, $21 \%$ had panic disorder, and $21 \%$ had obsessive-compulsive disorder. ${ }^{15-17}$

\section{Diagnostic and management challenges}

Accurate diagnosis continues to be a barrier to adequate treatment. The high rate of comorbidity with substance use makes it difficult to distinguish between mood lability secondary to drug and alcohol use versus a true bipolar spectrum. In the setting of substance abuse, bipolar disorder may be overdiagnosed. Goldberg et al found that only $33 \%$ of patients with active substance abuse suspected of having bipolar disorder met criteria after formal interview. ${ }^{18}$ High rates of misdiagnosis of unipolar depression have been reported. ${ }^{19}$

However, additional literature suggests that bipolar disorder may be underdiagnosed. Ghaemi et al found that $40 \%$ of bipolar patients were initially misdiagnosed, most commonly with major depressive disorder, and waited an average of 7.5 years before an accurate diagnosis was given. ${ }^{20}$ Other studies have also reported high rates of misdiagnosis with patients most commonly labeled with unipolar depression. ${ }^{2}$ Impediments to accurate diagnosis include failure to recognize hypomanic symptoms and frequent initial presentation with depressive features. ${ }^{21}$ Over $50 \%$ of BPAD patients will initially present with a depressive episode. ${ }^{22}$

Failure to accurately diagnose bipolar disorder can lead to improper treatment. Most frequently, patients are given antidepressants without mood stabilizers placing them at increased risk for switching into mania and/or rapid cycling as well as poor response to depressive symptoms. ${ }^{21}$ Additionally, bipolar disorder is associated with a higher risk of suicide than any other axis I disorder. An estimated 25\%-50\% of bipolar patients attempt suicide, with the majority of attempts occurring during depressive episodes..$^{22,23}$

Maintenance therapies have traditionally focused on mood stabilizers including lithium, valproic acid, carbamazepine, and, recently, lamotrigine. All agents have been shown to be effective relative to placebo in preventing relapses and typically need to be used in combination to control symptoms. ${ }^{24}$ Lithium has long been considered the gold standard of therapy. Relative to placebo, lithium use reduces the rates of manic or hypomanic episodes by $64 \%$ and depressive episodes by $30 \%-50 \% .{ }^{25}$ However, relapse rates on lithium have ranged from $20 \%$ to $40 \% .{ }^{26}$ Given the high relapse rate and extensive morbidity associated with this illness, additional therapies are needed.

The atypical antipsychotics have increasingly been used as an add-on and even monotherapy in bipolar spectrum disorders. Olanzapine was the first agent to gain US Food and Drug Administration approval for bipolar maintenance therapy. Relative to placebo, the relative risk of relapse on olanzapine for any episode has been estimated to be 0.6 and the number needed to treat, 4.2. ${ }^{27}$ Olanzapine has shown similar efficacy to lithium and divalproex. ${ }^{27}$ However, concerns about the metabolic side effects of olanzapine can lead to treatment discontinuation or adverse health outcomes. ${ }^{27}$

\section{Pharmacodynamics and pharmacokinetics of aripiprazole}

Aripiprazole, a quinolinone antipsychotic, is currently the only US Food and Drug Administration-approved atypical antipsychotic that is characterized uniquely as a partial agonist at the dopamine $\mathrm{D}_{2}$ receptor and serotonin $5-\mathrm{HT}_{1 \mathrm{~A}}$ receptor. ${ }^{28}$ Agonism of the $5-\mathrm{HT}_{1 \mathrm{~A}}$ receptor is thought to activate a cascade that results in inhibition of cortical pyramidal neurons, hormonal regulation, and may affect depression, anxiety, and cognition. ${ }^{29}$ Agonism of $\mathrm{D}_{2}$ receptor is thought to mediate psychosis and the dopaminereward system in the brain. Antagonism of the $\mathrm{D}_{2}$ receptor is thought to be responsible for antipsychotic efficacy, as well as undesired effects including affective blunting, worsening cognition, akathisia, parkinsonism, and hyperprolactinemia. Conventional and other atypical antipsychotics are full dopamine $\mathrm{D}_{2}$ receptor and serotonin $5-\mathrm{HT}_{1 \mathrm{~A}}$ receptor antagonists that do not allow receptor output. ${ }^{29}$ Aripiprazole, as a partial agonist, can partially activate the receptor to a lesser extent than a full agonist, yet attenuate, but not completely block, the receptor output. ${ }^{29}$ Through this mechanism, it creates a stabilizing balance between the $\mathrm{D}_{2}$ receptor and $5-\mathrm{HT}_{1 \mathrm{~A}}$ receptor output. ${ }^{29}$ Similar to other atypical antipsychotics, aripiprazole antagonizes serotonin $5-\mathrm{HT}_{2 \mathrm{~A}}$ receptors, which balances $\mathrm{D}_{2}$ receptor blockade and attenuates extrapyramidal side effects. Aripiprazole exhibits high receptor-binding affinity to dopamine $\mathrm{D}_{2}$, $\mathrm{D}_{3}$, serotonin $5-\mathrm{HT}_{1 \mathrm{~A}}, 5-\mathrm{HT}_{2 \mathrm{~A}}$, and $5-\mathrm{HT}_{7}$ receptors. ${ }^{28-30}$ This activity is thought to mediate psychosis, depression, anxiety, cognition, sleep, mood, learning, and memory. ${ }^{30}$ It has moderate affinity for $\alpha$-adrenergic $\alpha_{1}, \alpha_{2 \mathrm{C}}$, and histamine $\mathrm{H}_{1}$ receptors, which are associated with balancing 
dopamine blockade, hypotension, sedation, and cognitive impairment. ${ }^{28,30}$ Aripiprazole has no appreciative affinity for muscarinic $M_{1}$ cholinergic receptors that relate to low anticholinergic side-effect potential. ${ }^{28,30}$

Aripiprazole is metabolized hepatically primarily via cytochrome P-450 (CYP) 2D6 and 3A4 isoenzymes to its active metabolite, dehydroaripiprazole. ${ }^{28}$ This metabolite is thought to have receptor activity similar to that of aripiprazole but has an extended half-life. Steadystate serum concentrations consist of approximately $60 \%$ aripiprazole and $40 \%$ dehydroaripiprazole. The recommended adult dose for aripiprazole monotherapy treatment of bipolar I is $15 \mathrm{mg}$ once daily, which may be titrated to $30 \mathrm{mg}$ once daily if needed. ${ }^{28}$ Children aged $>10$ years may be initiated at $2 \mathrm{mg}$ aripiprazole daily and titrated to a target maintenance dose of $10 \mathrm{mg}$ aripiprazole daily. ${ }^{28}$ Concomitant therapy with CYP $3 \mathrm{~A} 4$ inducers, including carbamazepine, may increase clearance and lower serum concentrations of aripiprazole and dehydroaripiprazole by approximately $70 \% .{ }^{28}$ Effective doses of aripiprazole may need to be titrated to double the recommended maintenance dose when coadministered with strong CYP 3A4 inducers. Coadministration with CYP 2D6 inhibitors including quinidine and fluoxetine may increase serum concentrations of aripiprazole by approximately $112 \%$ and reduce serum concentrations of dehydroaripiprazole by $35 \% .{ }^{28}$ To compensate for these effects, effective doses of aripiprazole may need to be reduced by half when coadministered with CYP 3A4 inhibitors, such as ketoconazole and some antiretrovirals, or when coadministered with 2D6 inhibitors such as quinidine and fluoxetine. Currently, no dose adjustments are recommended for the elderly or individuals with hepatic or renal impairment.

Aripiprazole drug labeling currently includes pharmacogenomic dosing recommendations based on CYP 2D6 isoenzyme polymorphisms. Poor metabolizers at CYP 2D6 would result in an $80 \%$ increase in exposure to aripiprazole, and these individuals should have initial doses reduced by half. ${ }^{28}$ No initial dose adjustment is recommended for extensive metabolizers at CYP 2D6. The average half-life of aripiprazole is 75 hours for extensive CYP 2D6 metabolizers and 146 hours for poor metabolizers. ${ }^{28}$ The long half-life of aripiprazole allows for once-daily dosing of the drug. Steadystate serum concentrations can be reached in approximately 2 weeks but time to reach steady state may be doubled in CYP 2D6 poor metabolizers. Individuals' time to steady state may be considered when assessing efficacy and appropriate dose titrations of aripiprazole.

\section{Clinical data}

Aripiprazole stands apart from other atypical antipsychotics because of its unique mechanism of action through partial agonism at the $\mathrm{D}_{2}$ and $\mathrm{D}_{3}$ receptors as well as its $5 \mathrm{HT} 2 \mathrm{~A}$ antagonist properties and partial agonism at the $5 \mathrm{HT} 1 \mathrm{~A}$ receptor. It is less commonly associated with the metabolic side effects of olanzapine. ${ }^{31}$ Consequently, it is a good candidate for acute and maintenance treatment of BPAD.

Several studies have demonstrated aripiprazole to be effective in the acute treatment of mania and mixed states (summarized in Table 1). ${ }^{32-37}$ Sachs et al randomized 272 hospitalized patients with manic or mixed episodes to aripiprazole or placebo in a 3-week trial. Response was significantly higher with aripriprazole $(53 \%)$ relative to placebo (32\%) and this difference was evident as early as day 4. Discontinuation of treatment due to adverse effects was similar between the two groups. Target dosing was $30 \mathrm{mg}$ /day of aripriprazole and was maintained in $85 \%$ of patients. ${ }^{33}$ Similarly, in a 12 -week trial of 347 manic or mixed patients, Vieta et al found superior rates of response and tolerability in aripriprazole treated patients compared to those randomized to haloperidol. Response rates for aripiprazole treated patients were $50 \%$ compared to $28 \%$ of haloperidol patients. ${ }^{32}$ By week 12, 51\% of aripiprazole-treated patients, compared with $29 \%$ of haloperidol-treated patients, remained on therapy. Extrapyramidal side effects were also significantly higher in the haloperidol-treated group. Vieta et al showed apripriprazole produces significantly higher rates of response and remission compared with placebo when used as an adjuvant therapy to lithium and valproate during a 6-week double-blind placebo-controlled study involving 384 manic or mixed patients. At the end of 6 weeks, $50 \%$ of aripriprazole-treated patients were classified as remitters based on a Young Mania Rating Scale score $<12$ versus $36 \%$ of placebo-treated patients. Mean aripiprazole dose was $19 \mathrm{mg}$ /day. Aripiprazole-treated patients reported higher incidence of extrapyramidal symptoms. There were no differences between the aripiprazole and placebo groups on metabolic parameters. ${ }^{34}$ In a randomized doubleblind placebo-controlled comparative study with lithium, aripiprazole-treated patients demonstrated significantly greater response rates than placebo and similar rates to those observed with lithium at the 3 -week end point. ${ }^{35}$

The data on the use of aripiprazole in the maintenance phase are sparse. Following the 6-18 week stabilization phase, Keck et $\mathrm{al}^{38}$ randomized 161 recently manic or mixed patients to receive monotherapy with aripiprazole (78) or placebo (83) for an additional 100 weeks. The only 
Table I Aripiprazole in the acute treatment of bipolar affective disorder, manic, and mixed states

\begin{tabular}{|c|c|c|c|c|c|}
\hline $\begin{array}{l}\text { Study (reference } \\
\text { number) }\end{array}$ & Patients, $\mathbf{n}$ & Length & Treatment & Endpoint & Result \\
\hline 30 & $\begin{array}{l}347 \text { manic } \\
\text { or mixed }\end{array}$ & 12 weeks & $\begin{array}{l}\text { Aripiprazole, halolperidol } \\
\text { (double blind) }\end{array}$ & Response via YMRS & $\begin{array}{l}\text { Aripiprazole showed significantly } \\
\text { greater response rate relative } \\
\text { to haloperidol. } \\
\text { Greater incidence of EPS in } \\
\text { haloperidol group }\end{array}$ \\
\hline 31 & $\begin{array}{l}272 \text { manic } \\
\text { or mixed }\end{array}$ & 3 weeks & $\begin{array}{l}\text { Aripiprazole or placebo } \\
\text { (double blind) }\end{array}$ & $\begin{array}{l}\text { Mean change in YMRS, } \\
\text { response via YMRS }\end{array}$ & $\begin{array}{l}\text { Significantly greater YMRS } \\
\text { reductions and response observed } \\
\text { with aripiprazole. } \\
\text { No difference between groups in } \\
\text { discontinuation secondary to } \\
\text { adverse effects }\end{array}$ \\
\hline 33 & $\begin{array}{l}480 \text { manic } \\
\text { or mixed }\end{array}$ & 3 weeks & $\begin{array}{l}\text { Aripiprazole, lithium, } \\
\text { or placebo (double blind) }\end{array}$ & Mean change in YMRS & $\begin{array}{l}\text { Significantly greater reduction } \\
\text { in YMRS in ariprazole vs placebo, } \\
\text { similar reductions } \\
\text { in aripiprazole relative to lithium }\end{array}$ \\
\hline 34 & $\begin{array}{l}485 \text { manic } \\
\text { or mixed }\end{array}$ & 3 weeks & $\begin{array}{l}\text { Aripiprazole, placebo, } \\
\text { or haloperidol (double } \\
\text { blind) }\end{array}$ & Mean change in YMRS & $\begin{array}{l}\text { Significant reductions in YMRS } \\
\text { relative to placebo, similar to } \\
\text { haloperidol. } \\
\text { Aripriprazole associated with lower } \\
\text { incidence of EPS than haloperidol }\end{array}$ \\
\hline 35 & $\begin{array}{l}262 \text { manic } \\
\text { or mixed }\end{array}$ & 3 weeks & $\begin{array}{l}\text { Aripiprazole or placebo } \\
\text { (double blind) }\end{array}$ & $\begin{array}{l}\text { Mean change in YMRS, } \\
\text { response via YMRS }\end{array}$ & $\begin{array}{l}\text { Aripiprazole treated patients had } \\
\text { significantly greater mean reductions/ } \\
\text { response rates. } \\
\text { Discontinuation secondary to adverse } \\
\text { effects did not differ between groups }\end{array}$ \\
\hline 39 & $\begin{array}{l}384 \text { manic } \\
\text { or mixed }\end{array}$ & 6 weeks & $\begin{array}{l}\text { Adjunctive aripiprazole vs } \\
\text { placebo to lithium/valproate } \\
\text { (double blind) }\end{array}$ & $\begin{array}{l}\text { Reductions in YMRS, } \\
\text { Response/remission } \\
\text { via YMRS }\end{array}$ & $\begin{array}{l}\text { Significant reductions in YMRS, } \\
\text { significantly greater response/ } \\
\text { remission in aripiprazole treated } \\
\text { patients }\end{array}$ \\
\hline
\end{tabular}

Abbreviations: EPS, Extrapyramidal symptoms; YMRS, Young Mania Rating Scale.

concomitant medications allowed were lorazepam $2 \mathrm{mg} /$ day during the first month, $1 \mathrm{mg}$ /day during the second month, and $1 \mathrm{mg} /$ day up to four times per week for the remainder of the study. Anticholingerics were also allowed. Primary endpoint was time to relapse for a mood episode. Relapse was defined as hospitalization due to mood episode and/or addition or increase in psychotropic medication other than the study drug for mood symptoms. Mean dose of aripiprazole was $24 \mathrm{mg}$. On data analysis, aripiprazole-treated patients had a significantly longer time to relapse into mania than placebotreated patients. No differences were observed for depressive episodes. Fifty two percent of the aripiprazole- versus 33\% of placebo-treated patients experienced a relapse. ${ }^{38}$ No differences were observed between the groups in lipid, glucose, or weight changes. In a 46-week open-label extension following a 6-week double-blind phase of adjunctive aripiprazole to lithium or valproate in partial responders with bipolar mania, Vieta et al found adjunctive aripiprazole to lead to significant improvements in Young Mania Rating scores and
Montgomery-Asberg Depression Scale. ${ }^{39}$ Mean aripiprazole dose was $18 \mathrm{mg} /$ day. Other studies have also demonstrated aripiprazole to be effective as adjunctive therapy in patients with an inadequate response to lithium or valproic acid. ${ }^{40}$

\section{Conclusion and future directions}

The use of aripiprazole in the acute phase of manic and mixed episodes seems to be supported by the literature and is in line with common practice patterns where a primary mood stabilizer and antipsychotic are often started simultaneously. However, the dearth of data on aripiprazole as maintenance agents makes it difficult to recommend this during the maintenance phase over more established prophylactic agents such as lithium, valproic acid, and carbamazepine.

Although studies to date have demonstrated the potential for aripiprazole in the acute treatment phase and maintenance treatment of BPAD, additional data are needed to better clarify its role in the treatment of this disabling disorder, particularly in the maintenance phase. Due to the lesser incidence of 
metabolic side effects, aripiprazole is an attractive alternative to olanzapine, yet there are no head-to-head trials comparing either these two agents or aripiprazole to other atypical agents used in BPAD such as quetiapine or risperidone. Long-term maintenance studies comparing aripiprazole to lamotrigine and carbamazepine are also lacking. Additionally, no studies have been done comparing aripiprazole in combination with a mood stabilizer with two primary mood stabilizers such as lithium and valproate or carbamazepine. No research has examined its role in BPAD II.

\section{Disclosure}

The authors report no conflicts of interest in this work.

\section{References}

1. Sajatovic M. Bipolar disorder: disease burden. American J Manag Care. 2005;11(Suppl 3):S80-S84.

2. Hirschfeld RM, Lewis L, Vornik LA. Perceptions and impact of bipolar disorder: how far have we really come? Results of the national depressive and manic-depressive association 2000 survey of individuals with bipolar disorder. J Clin Psychiatry. 2003;64(2):161-174.

3. Goldberg JF, Harrow M. Consistency of remission and outcome in bipolar nad unipolar mood disorders: a 10 year prospective follow up. J Affect Disord. 2004;81(2):123-131.

4. Li J, McCombs JS, Stimmel GL. Cost of treating bipolar disorder in the California Medicaid (Medi-Cal) program. J Affect Disord. 2002; 71(1-3):131-139.

5. Williams M, Shah ND, Wagie A, Wood D, Frye M. Direct costs of bipolar disorder versus other chronic conditions: an employer-based health plan analysis. Psychiatr Serv. 2011;62(9):1073-1078.

6. Kessler RC, McGonagle KA, Zhao S, et al. Lifetme and 12-month prevalence of DSM-III-R psychiatric disorders in the Unites States. Results from the National Comorbidity Survey. Arch Gen Psychiatry. 1994;51(1):8-19.

7. Angst J, Gamma A, Lewinsohn P. The evolving epidemiology of bipolar disorder. World Psychiatry. 2002;1(3):146-148.

8. Angst J, Cui L, Swendsen J, et al. Major depressive disorder with subthreshold bipolarity in the National Comorbidity Survey Replication. Am J Psychiatry. 2010;167(10):1194-1201.

9. Zimmermann P, Brückl T, Nocon A, et al. Heterogeneity of DSM-IV major depressive disorder as a consequence of subthreshold bipolarity. Arch Gen Psychiatry. 2009;66(12):1341-1352.

10. Fiedorowicz JG, Endicott J, Leon AC, Solomon DA, Keller MB, Coryell WH. Subthreshold hypomanic symptoms in progression from unipolar major depression to bipolar disorder. Am J Psychiatry. 2011; 168(1):40-48.

11. Weissman MM, Bland RC, Canino GJ, et al. Cross-national epidemiology of major depression and bipolar disorder. JAMA 1996;276(4):293-299.

12. Lish JD, Dime-Meenan S, Whybrow PC, Price RA, Hirschfeld RM. The National Depressive and Manic-Depressive Association (DMDA) survey of bipolar members. J Affect Disord. 1994;31(4):281-294.

13. Hendrick V, Altshuler LL, Gitlin MJ, Delrahim S, Hammen C. Gender and bipolar illness. J Clin Psychiatry. 2000;61(5):393-396.

14. Bebbington P, Ramana R. The epidemiology of bipolar affective disorder. Soc Psychiatry Psychiatr Epidemiol. 1995;30(6): 279-292.

15. Regier DA, Farmer ME, Rae DS, et al. Comorbidity of mental disorders with alcohol and other drug abuse. Results from the Epidemiologic Catchment Area study. JAMA. 1990;264(19):2511-2518.
16. Chen YW, Dilsaver SC. Comorbidity of panic disorder in bipolar illness: evidence from the Epidemiologic Catchment Area Survey. Am J Psychiatry. 1995;152(2):280-282.

17. Chen YW, Dilsaver SC. Comorbidity for obsessive compulsive disorder in bipolar and unipolar disorders. Psychiatry Res. 1995;59(1-2): 57-64.

18. Goldberg JF, Garno JL, Callahan AM, Kearns DL, Kerner B, Ackerman SH. Overdiagnosis of bipolar disorder among substance use disorder inpatients with mood instability. J Clin Psychiatry. 2008;69(11):1751-1757.

19. Stewart C, El-Mallakh RS. Is bipolar disorder overdiagnosed among patients with substance abuse? Bipolar Disord. 2007;9(6):646-648.

20. Ghaemi SN, Sachs GS, Chiou AM, Pandurangi AK, Goodwin K. Is bipolar disorder still underdiagnosed? Are antidepressants overutilized? J Affect Disord. 1999;52(1-3):135-144.

21. Dunner DL. Clinical consequences of under-recognized bipolar spectrum disorder. Bipolar Disord. 2003;5(6):456-463.

22. Kupfer D, Frank E, Grochocinski VJ, Cluss PA, Houck PR, Stapf DA. Demographic and clinical characteristics of individuals in a bipolar disorder case registry. J Clin Psychiatry. 2002;63(2):120-125.

23. Dalton EJ, Cate-Carter TD, Mundo E, Parikh SV, Kennedy JL. Sucide risk in bipolar patients: the role of co-morbid substance use disorders. Bipolar Disord. 2003;5(1):58-61.

24. Muzina D, Calabrese JR. Maintenance therapies in bipolar disorder: focus on randomized controlled trials. Aust N Z J Psychiatry. 2005; 39(8):652-661.

25. Baldessarini RJ, Tondo L, Hennen J, Viguera AC. Is lithium still worth using? An update of selected recent research. Harv Rev Psychiatry. 2002;10(2):59-75.

26. Geddes JR, Burgess S, Hawton K, Jamison K, Goodwin GM. Long-term lithium therapy for bipolar disorder: systematic review and meta-analysis of randomized controlled trials. Am J Psychiatry. 2004;161(2):217-222.

27. Derry S, Moore RA. Atypical antipsychotics in bipolar disorder: systematic review of randomised trials. BMC Psychiatry. 2007;7:40.

28. Bristol-Myers and Squibb. Abilify Prescribing Information.

29. Stahl SM, editor. Stahl's Essential Psychopharmacology: Neuroscientific Basis and Practical Applications. 3rd ed. New York, NY: Cambridge University Press; 2008.

30. Challenges and solutions in developing new medications for schizophrenia. J Clin Psychiatry. 2010;71(10):1391-1399.

31. McIntyre R, Yoon J, Jerrell JM, Liauw SS. Aripiprazole for the mintenance treatment of bipolar disorder: a review of available evidence. Neuropsychiatr Dis Treat. 2011;7:319-323.

32. Vieta E, Bourin M, Sanchez R, et al. Effectiveness of aripiprazole v. haloperidol in acute bipolar mania: double-blind, randomised, comparative 12-week trial. Br J Psychiatry. 2005;187:235-242.

33. Sachs G, Sanchez R, Marcus R, et al. Aripiprazole in the treatment of acute manic or mixed episodes in patients with bipolar I disorder: a 3-week placebo-controlled study. J Psychopharmacol. 2006;20(4):536-546.

34. Vieta E, T'joen C, McQuade RD, et al. Efficacy of adjunctive aripiprazole to either valproate or lithium in bipolar mania patients partially nonresponsive to valproate/lithium monotherapy: a placebo controlled study. Am J Psychiatry. 2008;165:1316-1325.

35. Keck PE, Orsulak PJ, Cutler AJ, et al. Aripiprazole monotherapy in the treatment of acute bipolar I mania: a randomized, double-blind, placebo- and lithium-controlled study. J Affect Disord. 2009;112(1-3): 36-49.

36. Young AH, Oren DA, Lowy A, et al. Aripiprazole monotherapy in acute mania: 12-week randomised placebo- and haloperidol-controlled study. Br J Psychiatry. 2009;194(1):40-48.

37. Keck PE Jr, Marcus R, Tourkodimitris S, et al. A placebo-controlled, double-blind study of the efficacy and safety of aripiprazole in patients with acute bipolar mania. Am J Psychiatry. 2003;160(9): 1651-1658. 
38. Keck PE Jr, Calabrese JR, McIntyre RS, et al. Aripiprazole monotherapy for maintenance therapy in bipolar I disorder: a 100 week double blind study versus placebo. J Clin Psychiatry. 2007;68(10):1480-1491.

39. Vieta E, Owen R, Baudelet C, McQuade RD, Sanchez R, Marcus RN. Assessment of safety, tolerability and effectiveness of adjunctive aripiprazole to lithium/valproate in bipolar mania: a 46 week, open label extension following a 6 week double blind study. Curr Med Res Opin. 2010;26(6):1485-1496.
40. Marcus R, Khan A, Rollin L, et al. Efficacy of aripiprazole adjunctive to lithium or valproate in the long-term treatment of patients with bipolar I disorder with an inadequate response to lithium or valproate monotherapy: a multicenter, double-blind, randomized study. Bipolar Disord. 2011;13(2):133-144.

\section{Publish your work in this journal}

Therapeutics and Clinical Risk Management is an international, peerreviewed journal of clinical therapeutics and risk management, focusing on concise rapid reporting of clinical studies in all therapeutic areas, outcomes, safety, and programs for the effective, safe, and sustained use of medicines. This journal is indexed on PubMed Central, CAS,
EMBase, Scopus and the Elsevier Bibliographic databases. The manuscript management system is completely online and includes a very quick and fair peer-review system, which is all easy to use. Visit http://www.dovepress.com/testimonials.php to read real quotes from published authors.

Submit your manuscript here: http://www.dovepress.com/therapeutics-and-clinical-risk-management-journal 